\title{
HOW COMPETITION DRIVES BUSINESS TO DISARRAY??
}

\author{
Nagendra Hegde \\ Marketing, Indus Business Academy, India
}

\begin{abstract}
'Competition brings the best out' is an adage. We have had instances wherein few businesses benefitted from the intense competition, few acquired a gradual death and few an instant death. Today, competition has not gone well with many companies, who eventually failed to turn it in their favour. But, consumers surely have had a sweet bite in majority of the cases. This research article brings out the truth about the competition; how companies take competition, how is their preparedness to tackle competition, what an intense competition is likely to cause. Nowadays average firms react sharply to the competition. "The granddaddy of all mistakes is competing to be the best, going down the same path as everybody else and thinking that somehow you can achieve better results", says Michael Porter in his book "Essential Guides to Competition and Strategy". Firms tend to be reactive and act instantly while dealing with competition. They formulate strategies to garner immediate increase in sales, thereby compromising on fundamentals. If they do so, their ideology suffers, the principles on which they are built shatter. The infrastructure might start collapsing, resulting in betrayal of customers' trust in the long run. The research article examines various strategies used by two different firms and the results obtained thereafter. Firms have traditionally treated the strategies as the function of competition. The outcome of such strategies followed in line with the competition is unsettled results, inconsistent performances, loss of market share, etc. This cannot be substituted with disruptive approach for the very reason of it being unsustainable.
\end{abstract}

Keywords:

Competition, Correlation, Distribution, Disruptive Approach

\section{INTRODUCTION}

'Competition brings the best out' is an adage. We have had instances wherein few businesses benefitted from the intense competition, few acquired a gradual death and few an instant death. Joan Magretta [2] quotes Michael Porter saying, companies do mistakes. The biggest of them being thinking that somehow you can achieve better results. Few companies overestimate their strengths resulting in inward-looking bias. However, the most common and the worst mistake they commit is not having an adequate strategy at all. All these approaches make companies over-reactive, resulting a red-ocean.

Today, competition has not gone well with many companies, who eventually failed to turn it in their favour. But, consumers surely have had a sweet bite in majority of the cases.

This paper brings out the truth about the competition; how companies take competition, how is their preparedness to tackle competition, what an intense competition is likely to cause. The paper begins with a review of literature to arrive at research gaps and the objectives. The first section of the paper presents a case on Frooti Beverages (A Unit of Parle Agro Pvt. Ltd.). The sales operations of the company in Southern part of Karnataka are examined and the effects and results are discussed. The second section is on the Reliance Communications case, the competitive strategies of which are studied to arrive at conclusions.

\subsection{OBJECTIVES}

1. To determine the correlation between the productivity and the competition.

2. To understand to what extent the firms strategize in line with their competitors?

3. To analyse and understand how firms lose focus in a hurry to tackle the competition?

This paper brings out such strategies being followed by two Indian companies and the aftermath effects resulting out of that. One of them is a leading Packaged Fruit Juice company, Frooti Beverages and the other is a Telecom behemoth Reliance Communications Ltd.

The findings and expressions presented in this paper are for academic consumption only and do not intend to malign or derogate any individual or the organization concerned.

\section{LITERATURE REVIEW}

Many research papers, books and articles have been written about the competition, strategies and the profitability associated with that. Few of them substantiate what the author of this paper is intended to study. The snippets of them are given below.

\subsection{DOES COMPETITIVE ENVIRONMENT MODERATE THE MARKET ORIENTATION- PERFORMANCE RELATIONSHIP?}

The authors investigate how competitive environment affects the strength of the market orientation-performance relationship and whether it affects the focus of the external emphasis within a market orientation - i.e., a greater emphasis on customer analysis relative to competitor analysis, or vice versa, within a given magnitude of market orientation [3].

Narver and Slater state that Kohli and Jaworski [8] offer a foundation for theory of market orientation; they define market orientation as the generation and dissemination of market intelligence that is composed of information about customers' current and future needs and exogenous factors that influence those needs (e.g., competition and government regulations).

Narver and Slater's objective was to test whether competitive environment influences the form and effectiveness of business's market orientation.

Narver and Slater develop a measure of Market orientation and test its effect on business performance. Their measure of market orientation closely parallels Kohli and Jaworski's [8] definition and consists of three behavioural components (customer orientation, competitor orientation and interfunctional 
coordination). In cross sectional study, they find a substantial positive relationship between the magnitude of business's market orientation and its profitability.

\subsection{COMPETITION PERFORMANCE \\ AND \\ CORPORATE}

Nickell carried out a research across 670 UK companies to find out the relation between competition and the corporate performance. He says that his investigations indicate that there are some theoretical reasons for believing this hypothesis to be correct, but they are not overwhelming. He claims that he presents the evidence that competition, as measured by increased number of competitors or by lower levels of rents, is associated with a significantly a higher rate of total factor productivity growth [4].

\subsection{THE MARKET ORIENTATION - PERFORMANCE RELATIONSHIP IN THE CONTEXT OF A DEVELOPING ECONOMY: AN EMPIRICAL ANALYSIS}

The authors studied a sample of 162 manufacturing and service firms, only to find a positive correlation between market orientation and growth of the firms. The study further reveals that competitive hostility, suppliers' power and market turbulence did not moderate the market orientation- performance relationship [5].

\subsection{MODERN COMPETITIVE STRATEGY}

Gordon Walker studies the modern competitive strategies and suggests in his study that the firms should move away from competition to cooperation and coordination. He says that the competition driven strategies are traditional and the firms in the modern industrial economy can increase the benefits through cooperative approach. However, Walker admits that the customers benefit from the competition and that's how firms improve their performance [6].

\subsection{AN INTEGRATED APPROACH STRATEGIC MANAGEMENT}

TO

Hill and Jones offer an argument that a good organizational design, market structure (responsiveness to customer groups) coupled with competitive advantage of firms yield a superior profitability [7].

\subsection{GAP ANALYSIS}

The studied literatures talk about the positive relation between competition and the productivity. Most of these studies are done either before LPG (Liberalization, Privatization and Globalization) or post LPG. As many of them pointed out, traditionally the relation works out positively. However, the modern firms come with different challenges. They have a different challenge of attaining the sustenance, not just surviving the intense competition. In this context, the relevance of strategies derived just from the competition can be questioned. No study material or an existing research clearly talks about the firms' strategies in line with that. Unfortunately, we have many firms found strangled in the old league. Hence, the study is conducted to find the relevance of any competitive strategies.

\section{METHODOLOGY}

\subsection{SOURCES OF DATA COLLECTION}

Primary Sources - The data and information were obtained from the existing employees of Frooti Beverages and Reliance Communications Ltd. These employees are working in the capacity of Area Managers, Regional Managers and Sales executives. Few inputs were received from front line executives working off role.

Many findings are out of the experience of the Author during his stint in Parle Agro Pvt Ltd. and Reliance Communications Ltd.

Secondary Sources - Many Marketing journals, books on Strategies were referred to.

\subsection{APPROACH}

Simple analytical tools are used to analyse and interpret data. The sales strategies being followed by Frooti is examined from different angles and an astounding effect is closely monitored.

The author has tried to meet the objectives by studying the sales strategies followed by two companies. Idea of taking two companies is not to compare and contrast the sales strategies followed by them; the approach is basically to understand how two different firms working in two different competition intensive industries defy the effect of competition. No better businesses than FMCG and Telecom to undertake the objectives.

Scope: The study of Frooti's Sales Strategies is confined to South Karnataka markets.

Limitations: The accuracy of data obtained could be a factor of employees' accessibility and exposure to information depending upon their roles and experiences. Hence, the variation to the extent of $10 \%$ may be true.

\section{CASE 1 - PARLE AGRO PVT. LTD.}

The percapita consumption of soft drinks in India is projected to reach 8liters by 2020 [1]. Going by the growth rate of soft drinks in India (estimated to be at the rate of $25 \%$ to $30 \%$ ), the estimate is not far from reality. And meagre perks from the government and little promotional efforts from soft drink firms can trigger the per capita consumption.

The size of the non-fizzy soft drinks in India is estimated to be at Rs. $5580 \mathrm{Cr}$. The packaged juice segment makes $25 \%$ of the non-fizzy soft drinks. The share of the mango fruit drinks of the packaged juice segment is $75 \%$ to $80 \%$ (around Rs. $1100 \mathrm{Cr}$ ). Annual growth rate of mango based fruit drinks is pegged at $11 \%[1]$.

The packaged juice has become an all season product from what was deemed mere seasonal before. The huge potential for growth and the lucrative packaged fruit juice market are making organized and unorganized brands fight for share. Host of unorganized brands are giving organized brands a run for their money. Companies spend huge amount on marketing in an organized market. They hate to digest the fact that the unbranded products making a piggyback ride on their efforts and milking sales effortlessly. Unfortunately for organized Marketers, keeping such brands out of their way has been a daunting task and they are going all out to keep them at bay. The strategies are in line with 
these purposes and they seem to be going helter-skelter resulting in market blood-bath.

\subsection{FROOTI BEVERAGES (A UNIT OF PARLE AGRO PVT LTD.)}

Beverages industry is competition-intensive. Every organised brand has to compete with other organized brands, besides competing with host of unorganized brands. So, we shall start our journey from understanding the impact of competition on Frooti sales.

Frooti has been a familiar brand name among mango based packaged fruit juice lovers. The 50 years of its legacy has had a telling impact on its bottom-line till recently. The company has run into a rough weather off late due to various reasons, despite the decent growth rate of the industry. This paper tries to find out the reason.

\subsubsection{Details:}

The companies have to face competition from organized sectors head on. However, they can't afford to be frivolous of the challenges they face from unorganized sectors too. In few markets, unorganized brands dominate others. On an average, South Karnataka market is flooded with as many as 4-5 major unorganized brands. They are far too many to consider. Hence, we have chosen to study the impact of competition from only organized sectors.

Table.1. Competition to brand Frooti during last 4 years and the corresponding Sales Growth Rate in South Karnataka

\begin{tabular}{|c|c|c|c|c|c|}
\hline Year & $\begin{array}{l}\text { No. of Existing } \\
\text { Competition } \\
\text { (South KTK) }\end{array}$ & $\begin{array}{c}\text { Existing } \\
\text { Competitor }\end{array}$ & $\begin{array}{c}\text { New } \\
\text { Addition }\end{array}$ & $\begin{array}{c}\text { New } \\
\text { Competitor }\end{array}$ & $\begin{array}{c}\text { Growth in } \\
\text { Volume } \\
(\%)\end{array}$ \\
\hline 2011 & 4 & $\begin{array}{c}\text { Maa/ } \\
\text { Maaza/ } \\
\text { Sip On/ } \\
\text { Slice }\end{array}$ & 1 & Sparta & $\begin{array}{l}\text { Data not } \\
\text { available }\end{array}$ \\
\hline 2012 & 5 & $\begin{array}{c}\text { Maa/ } \\
\text { Maaza/ } \\
\text { Sip On/ } \\
\text { Slice/ } \\
\text { Sparta }\end{array}$ & 1 & Manpasand & $-2.2 \%$ \\
\hline 2013 & 6 & $\begin{array}{c}\text { Maa/ } \\
\text { Maaza/ } \\
\text { Sip On/ } \\
\text { Slice/ } \\
\text { Sparta/ } \\
\text { Manpasand }\end{array}$ & 0 & & $-35.6 \%$ \\
\hline 2014 & 6 & $\begin{array}{c}\text { Maa/ } \\
\text { Maaza/ } \\
\text { Sip On/ } \\
\text { Slice/ } \\
\text { Sparta/ } \\
\text { Manpasand }\end{array}$ & 0 & & $21.0 \%$ \\
\hline $\begin{array}{c}2015 \\
\text { (till } \\
10 \text { th } \\
\text { July) }\end{array}$ & 6 & $\begin{array}{c}\text { Maa/ } \\
\text { Maaza/ } \\
\text { Sip On/ } \\
\text { Slice/ } \\
\text { Sparta/ } \\
\text { Manpasand }\end{array}$ & 0 & & $12.5 \%$ \\
\hline
\end{tabular}

The correlation between the competition and the sales of Frooti is found to be negative.

Frooti seems to be having equal and strong contenders in South Karnataka Market throughout the last 4-5 years. Maaza from Coca Cola and Maaza from Cavin Care are giving brand Frooti a tough competition. 2012 and 2013 have been terrible years for Frooti as it had negative sales growth rates, before it bounced back to register a healthy growth rate of $21 \%$ in 2014 . The situation hasn't been different across India. Frooti had lost market share to its arch rivals Maaza and Slice (refer Table.2).

Table.2. All India Market Share of Frooti

\begin{tabular}{|l|c|c|c|}
\hline \multirow{2}{*}{ Brands } & \multicolumn{3}{|c|}{ Market Share (All India) } \\
\cline { 2 - 4 } & $\mathbf{2 0 1 2}$ & $\mathbf{2 0 1 3}$ & $\mathbf{2 0 1 4}$ \\
\hline Frooti & $18.60 \%$ & $13 \%$ & $15 \%$ \\
\hline Maaza & $24.70 \%$ & $37 \%$ & $40 \%$ \\
\hline Slice & $15.60 \%$ & $22 \%$ & $20 \%$ \\
\hline Others & $41.10 \%$ & $28 \%$ & $25 \%$ \\
\hline
\end{tabular}

South Karnataka fruit Juice market was Frooti's den till 2009 where it had a market share of around $37 \%$ which was believed to be at par with the national average. And there were no major competitors for Frooti other than not so aggressive Maaza and Slice. Everything was alright till competitors became aggressive. Parle Agro, the maker of the brand Frooti has woken up to a sudden splurge in competitive activities in the area. The company had no option but to react to the situation by altering few of its existing sales strategies.

However, it is strange to notice that Frooti fared equally badly in Mangalore Zone (part of South Karnataka comprising of Mangalore and Udupi districts), despite intensity of competition being less. Nevertheless, the available competition was strong enough to knock Frooti out of their way (refer Table.3).

Table.3. Competition to brand Frooti during last 4 years and the corresponding Sales Growth Rate in Mangalore Zone

\begin{tabular}{|c|c|c|c|c|c|}
\hline Year & $\begin{array}{c}\text { No. of Existing } \\
\text { Competition } \\
\text { (Mangalore } \\
\text { Zone) }\end{array}$ & $\begin{array}{c}\text { Existing } \\
\text { Competitor }\end{array}$ & $\begin{array}{c}\text { New } \\
\text { Addition }\end{array}$ & $\begin{array}{c}\text { New } \\
\text { Competitor }\end{array}$ & $\begin{array}{c}\text { Growth in } \\
\text { Volume (\%) }\end{array}$ \\
\hline 2011 & 3 & $\begin{array}{c}\text { Maaza/Sip } \\
\text { On/Slice }\end{array}$ & 0 & Nil & Not Available \\
\hline 2012 & 3 & $\begin{array}{c}\text { Maaza/Sip } \\
\text { On/Slice }\end{array}$ & 0 & Nil & $-7.8 \%$ \\
\hline 2013 & 3 & $\begin{array}{c}\text { Maaza/Sip } \\
\text { On/Slice }\end{array}$ & 0 & Nil & $-18.8 \%$ \\
\hline 2014 & 3 & $\begin{array}{c}\text { Maaza/Sip } \\
\text { On/Slice }\end{array}$ & 0 & Nil & $9.0 \%$ \\
\hline $\begin{array}{c}\text { 2015 } \\
\text { (till } \\
10 \text { th } \\
\text { July) }\end{array}$ & & $\begin{array}{c}\text { Maaza/Sip } \\
\text { On/Slice }\end{array}$ & 0 & Nil & Not Available \\
\hline
\end{tabular}

The Sales strategies with respect to the following are examined from hereon to find out the reasons for the Frooti debacle. 


\section{Distribution Strategies}

2. Manpower Strategies

\subsubsection{Distribution Strategies:}

Distribution Infrastructure - Infrastructure is a backbone of any business. Business sustenance is possible only through a solid infrastructure. We have had many instances amongst us wherein businesses could come out of tough times, thanks to their strong infrastructure. Having a strong distribution network provides FMCG companies a cushion, wherein a business hiccup can be shrugged off and businesses can reinvent themselves.

Table.4. Distribution Infrastructure of Frooti and the corresponding sales in South Karnataka

\begin{tabular}{|c|c|c|c|c|}
\hline \multicolumn{5}{|c|}{ South Karnataka } \\
\hline Year & $\begin{array}{c}\text { No. of } \\
\text { Distributors }\end{array}$ & $\begin{array}{c}\text { No. of } \\
\text { Outlets } \\
\text { Covered }\end{array}$ & $\begin{array}{c}\text { Sales in } \\
\text { Volume (in } \\
\text { No. of } \\
\text { Cases) }\end{array}$ & $\begin{array}{c}\text { Sales } \\
\text { Growth } \\
\text { in \% }\end{array}$ \\
\hline 2011 & 123 & 6936 & 380647 & \\
\hline 2012 & 117 & 7739 & 372640 & $-2.1 \%$ \\
\hline 2013 & 92 & $7352 *$ & 240063 & $-35.6 \%$ \\
\hline 2014 & 79 & $7200 *$ & 290559 & $21 \%$ \\
\hline 2015 (till & 93 & $8400 *$ & 201316 & $12.5 \%$ \\
\hline July 10th) & 93 & & & \\
\hline
\end{tabular}

*Note: Calculated considering the total retail outlet universe in South KTK in 2012 as 25640 (approx.). The growth in retail outlet base per year is projected to $10 \%$ (based on population growth which is $25 \%$ approx). Frooti Coverage is estimated to be at $70 \%$ of the retail universe maximum.

The Table. 4 shows that in last four years there is no stability in number of distributors. Number of distributors has gone down from 123 in 2011 to 79 in 2014 to 93 in 2015. In three years 44 distributors were sacked and within a year 14 more have been inducted, which means company is still experimenting with the coverage. The result is highly inconsistent sales volume.

There is a high volatility in coverage by number of retail and wholesale outlets as well. In 2011, 123 distributors were covering around 7000 retail and wholesale outlets (which is almost $58 \%$ of the retail universe in South Karnataka). There was a marginal increase in the coverage in 2013, going by the number of distributors present in 2013. Considering the growth of retail universe, year 2015 wouldn't have given Frooti a satisfaction. However, they could draw a solace themselves for at least not letting their grip on the existing outlets go.

There is certainly a positive correlation between the number of channel partners and the coverage of the market. But, the correlation has never been that strong (0.03). This is a clear indication of instability of the market coverage. Frooti never looked like settled down in the last four years.

The correlation between the number of retail outlets covered and the sales volume hasn't been encouraging $(-0.58)$. The reason for the sales loss with the increase in coverage is to do with frequency of servicing the markets. The sales growth and the consistency can be achieved only through a regular service of the markets. The coverage of only pockets would trigger the loss of the next-door image of a Seller, and hence may get their selling proposals rejected.

Table.5. Distribution Infrastructure of Frooti and the corresponding sales in Mangalore Zone

\begin{tabular}{|c|c|c|c|c|}
\hline \multicolumn{5}{|c|}{ Mangalore Zone } \\
\hline Year & $\begin{array}{c}\text { No. of } \\
\text { Distributors }\end{array}$ & $\begin{array}{c}\text { No. of } \\
\text { Outlets } \\
\text { Covered }\end{array}$ & $\begin{array}{c}\text { Sales in } \\
\text { Volume } \\
\text { (in No. of } \\
\text { Cases) }\end{array}$ & $\begin{array}{c}\text { Sales } \\
\text { Growth } \\
\text { in \% }\end{array}$ \\
\hline 2011 & 20 & 2255 & 72650 & \\
\hline 2012 & 20 & 2270 & 67014 & $-7.8 \%$ \\
\hline 2013 & 13 & $1985 * *$ & 54403 & $-18.8 \%$ \\
\hline 2014 & 13 & $2000 * *$ & 59318 & $9 \%$ \\
\hline 2015 (till & 13 & $2000 * *$ & 40941 & $-31 \%$ \\
\hline July 10th) & & & & \\
\hline
\end{tabular}

**Note: Calculated considering the total retail outlet universe in Mangalore zone is 3970 and growth of retail outlet base is kept approx at 5\% per annum. Year 2014 and 2015 outlet base is kept at approx maximum.

The case was little different for Mangalore Zone. The distribution operation was streamlined in 2013 and they seemed to have settled down with it. The resultant coverage and the sales have been encouraging for Frooti, even though they would have liked to touch their past glory.

\subsubsection{Channel Experimentation:}

Few of the strategies followed by the company in key towns of South Karnataka over a period of last 4-5 years reveal that it doesn't have a firm foothold in the market. The types of distribution followed in few key towns substantiate that.

In 2009, Bangalore town was subjected to two-line distribution. Two-line distribution system lets different distributors sell designated SKUs (Stock Keeping Units) to the retailers and the wholesalers in the same area. The purpose is to gain more mileage in terms of investment on all SKUs in the market, coverage and scaling up the business. It also strengthens the credit market which is an indirect and effective way of blocking the competition. Two-line distribution didn't work for long for various reasons and it had to be stopped.

Parle Agro again introduced two-line distribution selectively in Bangalore and Mysore towns in 2011 and had to stop after few months. In 2012, the company resorted to distributing brands Frooti and Appy through separate distributors. They had to stop this in 2013 and revert back to the age old practice of distribution.

Meanwhile, Parle Agro further streamlined its super stockiest based distribution system to cut down the cost of distribution. Super stockists were randomly removed, due to which many markets came into active coverage. The removal of Super stockists meant the loss of Distributors and the retailers in few areas, which means the markets which were under passive coverage went uncovered (which otherwise are not cost-feasible to cover). 


\subsubsection{The Real Problem:}

One definite issue being not protecting the channel profitability. The distributors are working for a markup of $5 \%$.

- Over $98 \%$ distributors and the super stockists have been on advance payment system.

- A little over $2 \%$ of the gross margin gets eroded due to market investments in the form of credit sales and the bad debts.

- $1.5 \%$ - $2 \%$ of the gross margin goes towards inventory maintenance and other operational costs.

Unfortunately, the effective margin of a distributor is only $0.5 \%$ to $1 \%$, which is very less considering the turnover (Average annual turnover a little above 5 lakhs).

The case was not so different for Super Stockists who worked on a flat commission of Rs. 10 per case sold till late 2011. That resulted in their incapability of shipping the goods further down to the channels on time, sometimes failure of shipments too. Inventory piled up at super stockiest places, which means, the SKUs were moved out of the warehouses 15-20 days after their prescribed holding time. By the time the products were sold to the consumers, they were either nearing expiry or in few cases expired too. This caused a rejection of the products and they started to bounce back in the form of damaged stocks. The sales staff and the channel partners' major time was spent in handling quality complaints. This caused a dent on a brand image.

The problems were multifold. Primary billings were reduced drastically; the frequency of billing has also reduced. Sales staffs were under tremendous pressure to perform. Till late 2013, Parle Agro was found experimenting with the number of sales staff (refer to Table.6 and Table.7)

Table.6. No. of employees and corresponding sales in South Karnataka

\begin{tabular}{|c|c|c|}
\hline \multicolumn{3}{|c|}{ South Karnataka } \\
\hline Year & $\begin{array}{c}\text { No. of } \\
\text { employees }\end{array}$ & $\begin{array}{c}\text { Sales in Volume (in } \\
\text { No. of Cases) }\end{array}$ \\
\hline 2011 & 37 & 380647 \\
\hline 2012 & 37 & 372640 \\
\hline 2013 & 26 & 240063 \\
\hline $\begin{array}{c}2015(\text { till } \\
\text { July 10th) }\end{array}$ & 31 & 201316 \\
\hline
\end{tabular}

Table.7. No. of employees and corresponding sales in Mangalore zone

\begin{tabular}{|c|c|c|}
\hline \multicolumn{3}{|c|}{ Mangalore Zone } \\
\hline Year & $\begin{array}{c}\text { No. of } \\
\text { employees }\end{array}$ & $\begin{array}{c}\text { Sales in Volume } \\
\text { (in No. of Cases) }\end{array}$ \\
\hline 2011 & 8 & 72650 \\
\hline 2012 & 9 & 67014 \\
\hline 2013 & 8 & 54403 \\
\hline $\begin{array}{c}\text { 2015(till July } \\
\text { 10th) }\end{array}$ & 11 & 40941 \\
\hline
\end{tabular}

The company lost many good distributors due to these volatile strategies. This affected the frequency of servicing the retail outlets, thereby affecting the cash rotation in the market, not to forget that this was at the cost of company's image.

The situation worsened during 2009-10, wherein the business in South Karnataka was thrown off gear. Few streamlining efforts that started in early 2011 could do little to resuscitate the otherwise dying business. The continuous trial and error strategies followed in sales and correction courses thereafter have led to business stability from late 2014 onwards. Following positive indications showed the sign of strengthening distribution infrastructure.

- Total 90 distributors in South Karnataka purchased stocks in 2011 compared to 63 in 2010.

- Billing efficiency increased to $68 \%$ in 2011 from $65 \%$ in 2010.

- Coverage in three key towns improved by $30 \%$ in 2011 over the previous year.

The above given positives could not revive the sales with immediate effect, which shows the extent of the aftermath effects of how Frooti business was carried out before. The following figures substantiate that.

- Sales from five key towns decreased marginally to 63000 cases in 2011 from 70000 cases in 2010 .

- The average annual purchase by a distributor decreased almost by $31 \%$ to 1254 cases as against 1817 cases in 2010 .

- The sales in volume decreased by $21 \%$ in 2011 over the previous year, despite a stronger distribution network.

This means, only few channels purchased beyond the potential of the market covered in 2010 and the years preceding. That indicates goods were infiltrated to different feeding markets causing unhygienic, unhealthy sales, thus creating a bubble in the market. This was a practice resulted out of competition driven by the unorganized sectors. People involved in it made quick money overnight. By the time the company realized this, it was too late to resurrect. It had to resort to a corrective course of action which did not yield positive results in the beginning.

The culprits were identified and were shown the exit door. The restrictions were imposed on sales through wholesale channel. Additional trade schemes, additional margins were stopped. Frequent price undercut practice followed by the previous sales system destroyed the entire market and the retail sentiment so much so that the new team really found it very difficult to do the business. Boosting the confidence of the sales force wasn't going to be an easy task, since they had tremendous unrealistic pressure resulting out of employer's expectation and a continuous rejection in the market place.

The strengthened distribution infrastructure couldn't revive the sales. But, the sales generated were genuine (predominantly from retail channels), hence the drop in volume. The health of the distribution found to have improved in 2011 , as many as $73 \%$ of the distributors being active in the business and the marginal improvement in billing efficiency.

Parle Agro never really took off after the debacle, which prompted it to adapt various trial and error methods to be in the fray. These were adhoc strategies by the company to tackle the competition, at the same time under the pressure to increase the 
profitability. The company was more worried of unorganized brands whose operations were aimed at short-term gains. All these were the reasons for a negative correlation between the channel strength and the sales growth (refer to Tables 4, 5, 6 and 7). When the channels do not yield the adequate result, they become a negative face of the firms, negating the very purpose of their existence.

\section{CASE 2: RELIANCE COMMUNICATIONS LTD.}

Last one decade and half has been a period of reckoning for Indian economy. There was no look back ever since a Foreign Direct Investment (FDI) cap was raised in Telecom sector which catapulted multi-faceted economic growth. It was from 2001 that India opened up to International markets with a flurry of private telecom operators waiting to unleash the domestic market potential. It took nearly a decade after LPG (Liberalization, Privatization and Globalization) was proposed to understand the scope it was offering, and probably another decade, to embrace the ripples it could create, especially in the telecom sector.

RCom (Reliance Communications, formerly Reliance Infocomm) was the first telecom operator in India to accelerate the tele-penetration in 2001. It was waiting to grab an opportunity and pounced on the market to take it from niche to mass; from a privilege to a basic right.

The path RCom took disrupted the market so in so that the rest of the telecom operators had to fall in place and fight for the survival.

\subsection{STRATEGIES ADOPTED BY RCOM}

A grubby competition started to unfold among telecom operators to capture a market.

Table 8. Priorities of RCom in \% weightage points over a period of time

\begin{tabular}{|c|c|c|c|c|c|}
\hline $\begin{array}{c}\text { Performance } \\
\text { Parameters }\end{array}$ & $\begin{array}{c}\text { 2001- } \\
04\end{array}$ & $\begin{array}{c}2005- \\
06\end{array}$ & 2010 & 2013 & 2015 \\
\hline Acquisition & $100 \%$ & $70 \%$ & $40 \%$ & $30 \%$ & $30 \%$ \\
\hline $\begin{array}{l}\text { Retention } \\
\text { (Churn } \\
\text { Management) }\end{array}$ & 0 & $10 \%$ & 0 & 0 & 0 \\
\hline Revenue & 0 & $15 \%$ & $30 \%$ & $30 \%$ & $20 \%$ \\
\hline $\begin{array}{l}\text { Manpower } \\
\text { Retention/ } \\
\text { Distribution } \\
\text { Infrastructure }\end{array}$ & 0 & $5 \%$ & $30 \%$ & $\begin{array}{c}5 \%- \\
\text { manpower } \\
\text { retention } \\
35 \%- \\
\text { distribution } \\
\text { infrastructure }\end{array}$ & $\begin{array}{c}10 \%- \\
\text { manpower } \\
\text { retention } \\
40 \%- \\
\text { distribution } \\
\text { infrastructure }\end{array}$ \\
\hline
\end{tabular}

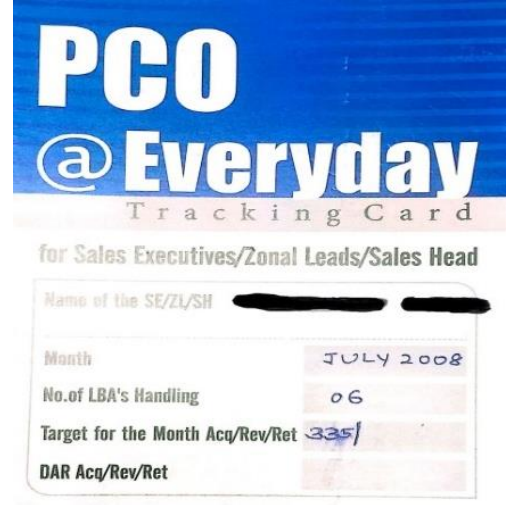

\section{RELIANCE PCO}

Fig.1. Sales Tracking Card

The Table. 8 shows how RCom's strategy changed over a period of time. The period 2001-04 reflected on company's history of carrying the business big. It had lot of firsts to its credit. The mobile phones were made affordable to a common man, which otherwise was a distant dream. The sleek, trendy mobile handsets with different features were released. The first data package was introduced through mobile. Obviously the strategy was to target the mass and stamp an authority. So, the company resorted to predatory pricing, through which it went on Acquisition spree; the mobile phones have started to get traded for the first time as commodities. At least 2 out of 5 people owned more than one mobile set. The company started tracking the daily sales employee wise in 2008 which talks about its excessive focus on Acquisition (Fig.1 and Fig.2 show the sales tracking card with respect to one of the Telecom products). Each sales employee irrespective of the level they are in was given the tracking sheets and their sales performance was monitored. The employees had a daily acquisition target, and the revenue target was not given due importance. The main competitors were Airtel and Hutch. None of them could match RCom with respect to the number of acquisitions made.

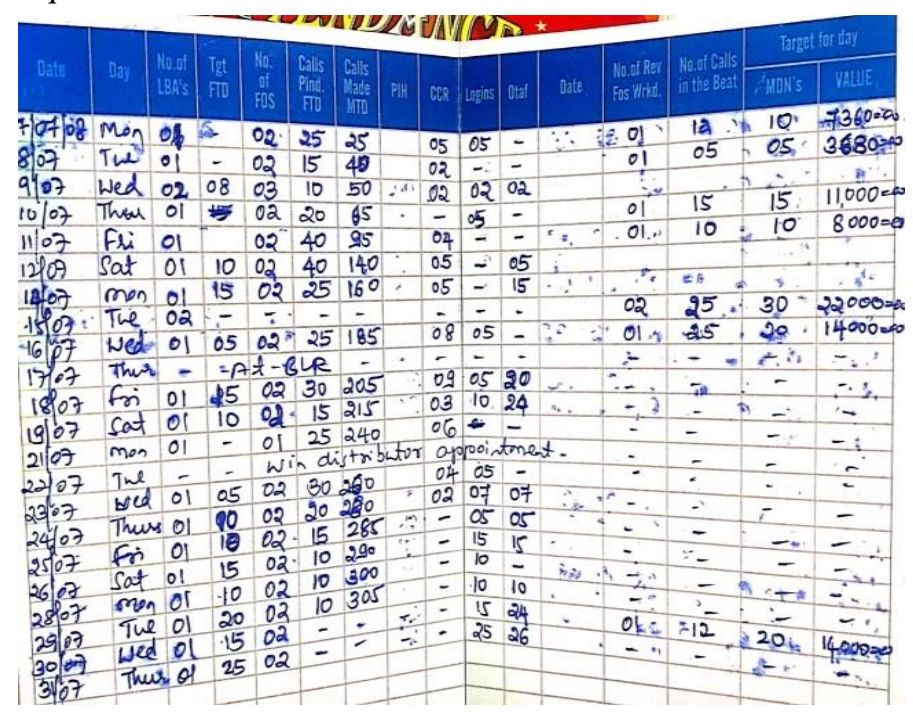

Fig.2. Daily Sales Track Card

Year 2005-06 saw competition growing with the entry of few more telecom operators. Even a government operated BSNL came 
out from the hibernation to make its presence felt. They saw an opportunity in disgruntled RCom customers who were the victims of firm's operating inefficiency. The company had an aggressive acquisition approach even before getting its ground infrastructure completely ready. What followed was a severe service failure; customers have started moving out of Reliance network. The success it enjoyed initially was nullified by poor planning and short-term orientation. It's then the company realized and changed its approach from full acquisition to Customer Retention, increasing Average Revenue per User (ARPU), Manpower Retention and strengthening channel infrastructure.

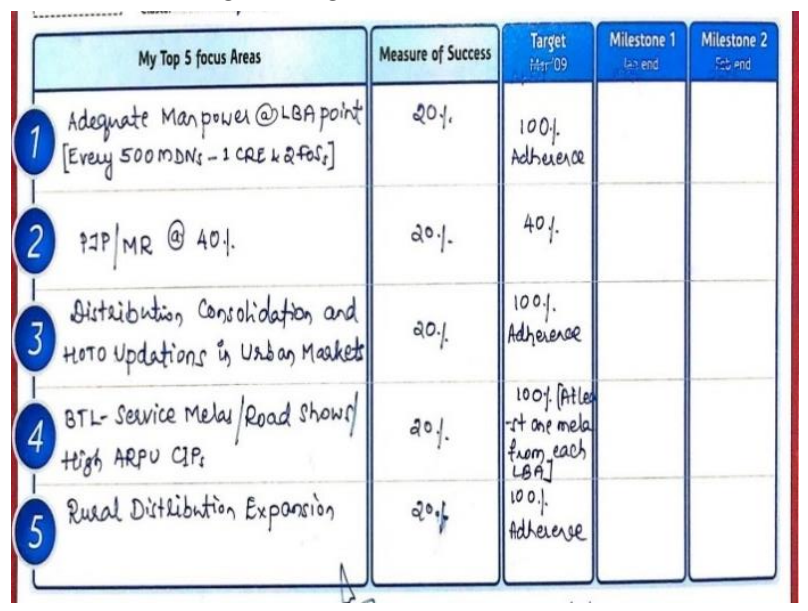

Fig.3. Key Focus Areas of RCom Employee in 2009

Other telecom operators have responded to RCom's aggressive approach slowly, but they gradually moved up. Table 8 clearly shows how RCom had to change its priorities after 2004. Now more than $70 \%$ weightage of priority is given to strengthening distribution infrastructure, employee performance and the ARPU. RCom has been in a catching up business ever since, and has been trying to compensate the lost business.

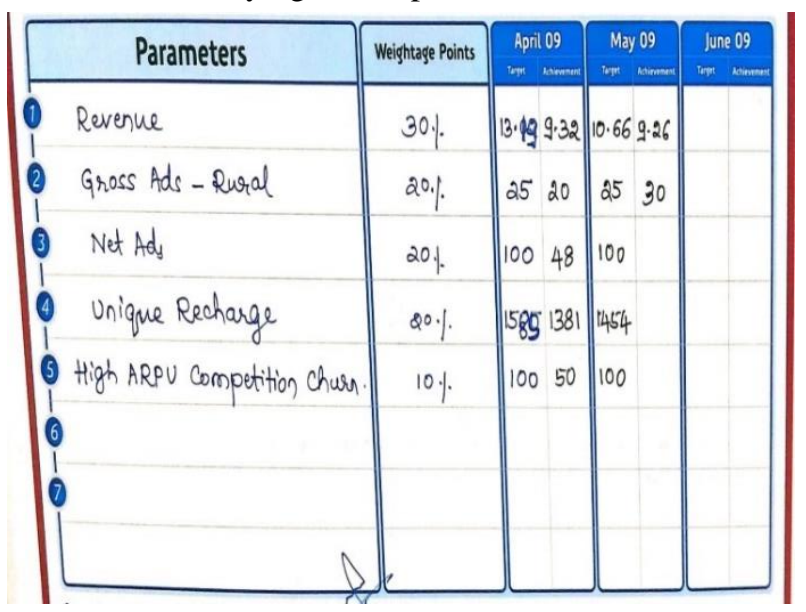

Fig.4. KPIs of RCom Employee in 2009

A gradual shift in the focus areas of RCom in 2009 can be seen from Fig.3 and Fig.4 respectively. More weightage is seen assigned to Retention of customers, the revenue generation and infrastructure development. The emphasis on the Net Additions (Net Adds) gained equal importance at $20 \%$ along with Gross Additions (Gross Adds). This was a corrective course of action RCom adopted after the initial revenue loss.
The telecom business has lot to offer to the Indian market which still has unfulfilled needs and has lot of potential. No doubt, RCom with its unconventional approach has dictated the market and the competitors, but only for a shorter period and unfortunately has fallen by its own petard. The case is no lesser than the race between the hare and the tortoise. The wrong approach could lead you out of the race or least, you could be left at the mercy of competitors and the customers.

The change in the business model came little late for RCom; by the time it did, it had lost a major chunk of its customers to its competition.

\section{FINDINGS}

The correlation between the competition and the sales of Frooti is found to be negative. The entry in packaged juice segment is not a barrier which makes the product susceptible for commoditization. Therefore, the brands like Frooti have to fight with host of unorganized brands which are mushrooming exorbitantly. There is no guarantee that those brands last till the next summer. They make the fast business and vanish. No doubt, they spoil the party; but, not to the extent few companies have found themselves in. This is a clear case of reacting sharply to a competition and thereby becoming a victim of your own strategies. Surprisingly Frooti's sales growth was negative despite less competition in Mangalore Zone.

The correlation between the number of channel partners and the coverage of the market was positive. But, the correlation has never been that strong (0.03). This is a clear indication of instability of the market coverage. Frooti paid price for playing too much with its distribution infrastructure while countering competition. Channel partners are the first touch points and they need to be Reliable and responsive. They were not given adequate attention to, their interests were not protected. The business proposition was never a win-win. Because, both the expected outcome and the return were unrealistic. So, they backed off or have become defunct resulting in service failure and the subsequent sales becoming inconsistent and highly nonpredictable. It was a vicious circle that it affected employee performance as well.

RCom's case reflects on how competition dictates terms on firms' strategies. It was an example of a hunter becoming hunted. The telecom operator became so predatory in approach that it never realized that customers are leaving its network. The company had a negative profit for few years, its brand value eroded. If that was not enough, customers were not willing to dial Reliance again. The result of its inefficiency was so severe, that it had to reform its strategies and the business model in line with the strong competition. Unlike in Frooti's case, RCom had to compete with tougher opponents. We would never have heard from Reliance again, had it been any other firm, not backed up by strong infrastructure. So, being disruptive doesn't make good either, being utility focused does.

Firms employ different strategies to protect their resources, core capabilities and customers from competitors. While doing so, many firms compromise on their fundamentals, core capabilities in a bid to over score competition in the short run. This can be detrimental. It is ideal to prevent customers from moving to substitute products with a right appealing. To defend the superior 
positions in the market, firms should strengthen their core competencies.

\section{CONCLUSION}

"The granddaddy of all mistakes is competing to be the best, going down the same path as everybody else and thinking that somehow you can achieve better results", says Michael Porter in his book "Essential Guides to Competition and Strategy" (refer [2]). Few firms tend to be reactive and act instantly while dealing with competition, while few disrupt the market to be in the fray. They formulate strategies to garner immediate increase in sales, thereby compromising on fundamentals. When they resort to this, their ideology suffers, the principles on which they are built shatter. Being overtly competitive cannot be substituted with disruptive approach for the very reason of it being unsustainable. Such short-term strategies expose the firms' weaknesses and make them further vulnerable to competition. The result would be a blood-bath. By doing this, firms often repeat the mistakes, thereby losing efficiency. The infrastructure might start eroding resulting in betrayal of customers' trust in the long-run. The strategy in line with the competition is traditional way of driving the business. Today it is very important to sustain in the business than just to survive the competition. Therefore, the collaborative and cooperative approach is the necessity to survive in the long run. The win-win value proposition with all stakeholders of the company should be the right strategy to survive in market turbulence.

\section{APPENDIX}

South Karnataka Markets comprise of Bangalore rural, Kolar, Mysore, Chamarajnagar, Madikeri, Hassan, Mangalore, Chikmagalur, Shimoga, Udupi and Tumkur Districts.

\section{REFERENCES}

[1] Anita Sharan, "More Than a Summer Drink", Available at: http://www.parleagro.com/news.html, Accessed on 2015.

[2] Joan Magretta, "Understanding Michael Porter-Essential Guides to Competition and Strategy", $1^{\text {st }}$ Edition, Harvard Business Review Press, 2011.

[3] Stanly F. Slater and John C. Narver, "Does Competitive Environment Moderate the Market Orientation-Performance Relationship?", Journal of Marketing, Vol. 58, No. 1, pp. 46-55, 1994.

[4] Stephen J. Nickell, "Competition and Corporate Performance", Journal of Political Economy, Vol. 104, No. 4, pp. 724-746, 1996.

[5] Ram Subramanian and Pradeep Gopalkrishna, "The Market Orientation-Performance Relationship in the Context of Developing Economy: An Empirical Analysis", Journal of Business Research, Vol. 53, No. 1,pp. 1-13, 2001

[6] Gordon Walker, "Modern Competitive Strategy", $2^{\text {nd }}$ Edition, McGraw Hill, 2008.

[7] Charles Hills and Gareth Jones, "Strategic Management: An Integrated Approach", South-Western College Publishing, 2012.

[8] Ajay K. Kohli and Bernard Jaworski, "Market Orientation: The Construct, Research Propositions, and Managerial Implications”, Journal of Marketing, Vol. 54, pp. 1-15, 1990. 